\title{
ISRAEL'S NUCLEAR WeAPONS: The White House Factor
}

\author{
Jeremy Salt
}

\begin{abstract}
Dr. Salt is an associate professor of political science at Bilkent University in Ankara.
\end{abstract}

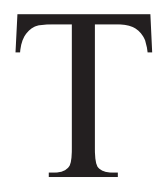
he assassination of President John F. Kennedy in 1963 was to have a profound and longlasting effect on U.S. Middle East policy. The accession to power of Lyndon Baines Johnson put into the White House a man who regarded himself as Israel's best presidential friend since Truman and proceeded to demonstrate the point by transforming the relationship between the United States and Israel. During the Johnson presidency, the opportunity arose to use the supply of tanks and planes as leverage to compel Israel to sign the forthcoming Nuclear Non-Proliferation Treaty (NPT) ${ }^{1}$ and place all its nuclear installations under international safeguards, in line with U.S. nonproliferation policy. Initially, Johnson sought to write conditions into arms contracts that would require Israel to forgo the development of nuclear weapons. Over the years, however, not one of the conditions the United States regarded as vital to its own national security was met. On the most reliable evidence, Israel already had nuclear weapons, or had all the components in place for quick assembly, by the time it attacked Egypt and Syria on June 5, 1967.

The long-term implications were clear. The states around Israel would never resign themselves to living forever in the (C) 2010, The Author shadow of Israel's nuclear "deterrent." Sooner or later, one of them would most likely try to develop nuclear energy and perhaps a nuclear deterrent of its own. This is the point that Israel claims Iran is now close to reaching.

Even in the shah's time, the U.S. administration was concerned with nuclear development in Iran. Iranian objections to American interference were strikingly similar in spirit to those expressed by the current Iranian government, i.e., that Iran would not accept "discriminatory treatment" or treatment as a "second class citizen." In the shah's view, "You are asking us for safeguards that are incompatible with sovereignty, things that the French or Germans would never dream of doing .... Such safeguards are absolutely unnecessary, because Iran is a signatory to the Non-Proliferation Treaty." 3 The government of the Islamic republic says it has no intention of developing nuclear weapons. Both the International Atomic Energy Agency (IAEA) and the National Intelligence Council (NIC), the peak body for all U.S. intelligence agencies, concur that there is no evidence of Iran's moving towards weapons development and production. Dr. Muhammad ElBaradei, the recently retired head of the IAEA, reported 
Middle East Policy, Vol. XVII, No. 3, Fall 2010

in June 2008 that the agency, despite some problems with transparency, "has been able to verify the non-diversion of declared nuclear material in Iran.". ${ }^{4}$ Even if Iran did want to produce a nuclear weapon, the NIC found in 2007, "We judge with high confidence that Iran will not be technically capable of producing and reprocessing enough plutonium for a weapon before about 2015." 5 In the Iranian view, the U.S. demand that it abandon its uranium enrichment program or place it under the control of other states ${ }^{6}$ amounts to a form of neo-imperialism designed to preserve Israel's position as the only nuclear state in the region and keep the Middle East under Western control.

\section{CONDITIONS}

Israel's nuclear-development program dates back virtually to the moment of its creation out of Palestine. Israeli scientists believed that the Naqab (Negev) might be a source of uranium, and indeed small amounts were found and extracted from phosphate deposits. In 1955, Israel signed a nuclear-cooperation agreement with the United States under President Eisenhower's Atoms for Peace program and in 1957 began the construction of a small "experimental" nuclear reactor at Nahal Soreq. In October 1957, France agreed to supply Israel with a 24-megawatt reactor at what was to become known as the Dimona nuclear plant. By 1964, the reactor had gone critical. In public statements, high Israeli government representatives variously described what was taking shape in the Negev as a textile plant, an arid-land research plant or a metallurgical research plant.

When it was no longer possible to deny the nuclear nature of the plant, Israel insisted that it was developing nuclear energy only for peaceful purposes.
At the same time, as it was embarking on the road to nuclear-weapons development, Israel was hoping to acquire tanks and planes from the United States. In the Kennedy years, it had been supplied with a consignment of Hawk surface-to-air "defensive" missiles, but the refusal of the United States to become a direct supplier in the Middle East "arms race" had forced it to look elsewhere. Its main suppliers were France and Britain, the former providing warplanes (Super Mystère, Vautour and Mirage fighters) and the latter tanks (Centurions). A surreptitious program in 1964 to provide Israel with refurbished American M48-A1 Patton tanks through Germany and Italy collapsed after being exposed in the media.

The Johnson administration then took the historical decision to become a direct and open supplier of weapons to Israel. The president himself penned a memo attaching four conditions to the supply of tanks, insisting that they must be considered a package "and accepted as such."7 Three of these conditions required Israel to support the supply of arms to Jordan, to keep secret all matters under discussion, and to reiterate its commitment to not build nuclear weapons. In the fourth, Johnson wrote that the United States "cannot accept Israeli preemptive action against the Arab [water] diversion works but must instead have Israeli agreement to take this problem to the United Nations." Johnson also expressed U.S. opposition to "preemptive" strikes against Jordan, a country that had neither the military means nor the intention to launch any action that would warrant a "preemptive strike."

On this basis, the White House approved the direct supply of Patton tanks to Israel in February 1965. Johnson had seemed to go along with the State De- 
partment view that, in return for U.S. tanks, Israel should be prepared to accept international supervision of its nuclear program. But eventually he backed off. "Given the strengthening of Israeli security by the actions we contemplate [i.e., the supply of tanks], we wish a firm reiteration of Israel's intentions not to develop nuclear weapons and that Israel certify this by accepting IAEA safeguards on all of its nuclear facilities," he wrote. However, "so long as we receive the pledge, ... I do not insist on acceptance of IAEA controls now."

Johnson's refusal to put pressure on Israel clearly lay in his perceptions of the power of the "Jewish lobby" to support him or damage him (as well as in his disappointed hope that, in return for his support of Israel, American Jews would support his policies on Vietnam). A wily, calculating politician, he had been a strong "supporter" of Israel since the 1940s. His circle of friends included Arthur and Mathilde Krim, Supreme Court Justice Abe Fortas and Abe Feinberg, all of them powerful figures within the lobby. Key positions in the administration and the White House were filled by ardent supporters of Israel (both Jewish and non-Jewish), with Johnson also maintaining an extremely close personal relationship with a senior diplomat at the Israeli embassy, Ephraim Evron. Johnson was given to ruminations on the parallels between the settlers of the Old West and the Zionist settlers of Palestine, but domestic self-interest, and not emotion, was the decisive element in the relationship he forged with Israel. Even among his own senior officials, the close relationship with Israel was not universally regarded as being in the best interests of the United States. As the American ambassador to Cairo remarked in 1964, "Israel's interests (as determined by Israel) do not at all times and in all respects coincide with those of the United States." 10

Having secured tanks, Israel then began campaigning for the supply of aircraft. Senior administration figures were hesitant, if not openly opposed. U.S. policy, wrote one advisor, had been "a major factor in keeping us out of the Near East arms race and protecting the United States from the political damage that would result from a policy of uncontrolled military sales." 11 In March 1966, however, the United States agreed to sell Israel 24 Skyhawk A4e "intruder type" aircraft, with the option left open for it to buy 24 more at a later date. During the plane negotiations, the State Department tried to write a clause into the sales agreement placing restrictions on Israeli nuclear development. However, it succeeded only in extracting what was to become the standard response from Israel, that it would not be the first country to introduce nuclear weapons "into the ArabIsraeli area." 12

What was going on at Dimona remained a matter for speculation. By early March 1965, Rodger P. Davies, the director of the State Department's Office of Near Eastern Affairs, reported the conclusion of the embassy staff in Tel Aviv: Israeli scientists were preparing "all necessary elements for production of a nuclear device, leaving undone only last-minute assembly." 13 The "target date" for the acquisition of nuclear weapons was $1968-69 .{ }^{14}$ In talking points given to Johnson ahead of the visit to Washington by Israeli Prime Minister Levi Eshkol (January 7-8, 1968), it was noted under the header, "what we want": "We think we have an acceptable NPT. We believe this will serve Israel's long-term security. We expect Israel to sign." 15 Yet, Eshkol 
Middle East Policy, Vol. XVII, No. 3, Fall 2010

visited Washington as planned and died on February 26, 1969, without having to budge from the formula that Israel would not be the first state to "introduce" nuclear weapons into the region.

\section{LAST BEST CHANCE}

In fall 1968, with Johnson having announced on March 31 that he would not seek re-election, the pending supply of F-4 Phantom fighter aircraft to Israel became a campaign issue. On October 14, Harold Saunders reiterated the State Department view that a decision to supply them should be linked to Israeli commitments to sign the NPT, to go no further in the development of surface-to-air missiles and to reaffirm assurances that Israel would not be the first state to introduce nuclear weapons into the region. ${ }^{16}$ Parker T. Hart, of State's Near Eastern Affairs (NEA) bureau, believed that, because the supply of Phantoms would end the long-standing U.S. policy of not being the principal supplier of Israel's weapons needs, the United States was entitled to seek something in return. ${ }^{17}$ The obvious pressure point was Israel's nuclear and missile policy. Evidence pointing to Israeli development of nuclear weapons was already on the table, with the latest intelligence indicating that Tel Aviv was also "moving rapidly towards obtaining and deploying strategic missiles." Israel was reported to have received from France two MD-620 missiles (capable of reaching Cairo), five more were expected to arrive by mid-1969, and the "covert construction" of missile-launching and production facilities had been uncovered. In addition, "there is a report that Israel intends to provide nuclear warheads for the MD-620 missiles." 18

There could be no point in Israel's spending so much on missile research if the option of fitting missiles with a nuclear warhead "is not the principal consideration," Hart wrote. Accordingly, the coming negotiations over the supply of fighter aircraft represented "our last best chance" to prevent Israel from developing nuclear weapons. "We believe we are dealing with a matter that not only has a crucial bearing on the Arab-Israeli problem but also directly affects U.S. security interests. If Israel builds a bomb, it will be the first small state to do so, and that fact will have a profound effect on our efforts to keep the other near-nuclears from going over the threshold." 19 Less than a week later, however, Johnson assured Israeli Foreign Minister Abba Eban that he would not make adherence to the NPT a formal condition of sale. ${ }^{20} \mathrm{He}$ also told Secretary of State Dean Rusk that he remained "strongly opposed to twisting arms on the nuclear thing in connection with Phantoms." 21

In a meeting with Israeli ambassador Yitzhak Rabin in early November, Under Secretary of Defense Paul Warnke repeated the assurances the United States was seeking, without getting any satisfaction from him. ${ }^{22}$ Almost certainly, Rabin knew he had the president behind him. Just the day before his meeting with Warnke, Johnson had invited Rusk, Clark Clifford, Walt Rostow, CIA director Richard Helms and Generals Maxwell Taylor and Earle Wheeler to a working lunch at the White House. When Clifford and Rusk argued strongly that conditions be attached to the sale of Phantoms, Johnson told them "he had promised the F-4s without any conditions and that was his position." ${ }^{23}$ When Rabin and his team walked into Warnke's office the following day, "It was abundantly clear that they had been told of the President's position and of his instructions to the Secretaries of Defense and State." ${ }^{24}$ The discussion that followed between 
Warnke and Rabin remains interesting to read, but with Johnson blocking any pressure, the Israeli ambassador knew he did not have to budge. ${ }^{25}$

On November 27, Warnke confirmed the agreement of the United States to sell Israel 50 F-4 Phantoms and related equipment and services, noting that he had made it clear that the United States would regard the "physical possession and control of nuclear arms by a Middle Eastern power" as constituting the "introduction" of nuclear weapons, thereby creating circumstances entitling the United States to cancel armssupply contracts. There was no mention of Israel's adherence to the NPT in the present or the future. ${ }^{26}$

\section{NO PRESSURE}

The end of the Johnson presidency ushered into the White House a man who would become an even better friend of Israel. Richard Nixon's world was ruthless, expedient and utterly pragmatic. His real achievements in domestic and foreign policy, especially detente with China and the USSR, were overshadowed by the deception and lies that characterised his presidency. The leaking of the Pentagon Papers in 1971 showed that he had authorized the secret bombing of Cambodia and Laos. The Watergate scandal of the following year exposed the attempt by his Committee to Reelect the President (CREEP) to break into the Democratic Party's national headquarters for the purpose of planting bugging devices. Impeachment proceedings had already been initiated against Nixon when he resigned on August 9, 1974. Nixon's Middle East policies were shaped within the greater global framework of U.S. rivalry with the Soviet Union. His alleged anti-semitism has long since been a matter of debate. Off-the-record jokes and slurs ("cheap kike"), suspicion of Jewish influence within the bureaucracy (his reference to a "Jewish cabal" in the Bureau of Labor Statistics), accusations that American Jews put Jewish interests first, and the standard view that the media was in the grip of a Jewish "stranglehold" provide plenty of ammunition for these accusations. ${ }^{27}$ Yet, many of Nixon's senior advisers were Jewish, and his support for Israel was solid. Golda Meir regarded him as "my President." In Henry Kissinger's view, "in every crisis Nixon stood by Israel more firmly than almost any other President save Harry Truman." 28 One measure of his support was foreign aid for Israel, which reached a high of $\$ 126.8$ million (1966) during the Johnson presidency, then soared to $\$ 2.6$ billion (1974) during the Nixon years, amounting to an exponential rise over the annual aid allocation to Israel in 1971 of \$634.3 million, in 1972 of $\$ 430.9$ million, and in 1973 of $\$ 492.8$ million. ${ }^{29}$ If Lyndon Johnson gave Israel a green light to start one war (the Six-Day War) by supporting its attack on Egypt and Syria in 1967, Richard Nixon saved it from possible defeat in another (the 1973 attack by Egypt and Syria on Israeli positions in the occupied Sinai and the occupied Golan Heights) by authorizing a massive airlift of military supplies, some directly to Israeli military positions in Sinai. None of these positions were necessarily contradictory or mutually exclusive. Kissinger believed that the president's prejudices were typical (and one might say reflexive) of the "uprooted California middle class from which he came." ${ }^{30}$ These personal prejudices were not reflected in his political relationships and foreign policy. Although he believed that Israel's occupation of Arab lands was stimulating radicalism, Syria, Egypt and Iraq all had close military, economic and 
Middle East Policy, Vol. XVII, No. 3, Fall 2010

political ties with the USSR. Israel's relationships lay with the United States and the West, in general. In the context of the Cold War, Nixon would do what he could to ensure that Israel maintained a military edge over the Arab states and their Soviet backer. Israel's nuclear program added a new dimension to both the conflict between the Arabs and Israel and between the United States and the USSR. ${ }^{31}$

Although there are indications that Johnson knew Israel had produced a nuclear weapon by early 1968 at the latest, attempts to compel Israel to abandon its nuclear weapons program and sign on to the NPT continued into the Nixon presidency. The new president's position on nonproliferation was set out in National Security Decision Memorandum (NSDM) 6 issued on February 5, 1969. He had decided to move ahead with U.S. ratification of the NPT, but "there should be no efforts to pressure other nations, in particular the Federal Republic of Germany, to follow suit. The government in its public posture should reflect a tone of optimism that other countries will sign or ratify while clearly dissociating itself from any plan to bring pressure on these countries to sign or ratify." 32

As the only small country suspected of developing nuclear weapons, Israel was the subject of a memorandum written on February 7 by Henry Owen, chairman of the State Department's Policy Planning Council. Owen outlined the dangers of an Israeli nuclear-weapons capability: other countries would be more likely to develop nuclear weapons and less likely to sign the NPT, while Arab frustrations would increase, and U.S. influence in the region would suffer a major setback. Furthermore, the introduction of nuclear weapons would also increase the risk of war between Israel and the Arab states and perhaps a nuclear confrontation between the United States and the USSR. For Owens, only if Israel believed the U.S. government was prepared to take the issue into the political arena "will it consider the threat of U.S. displeasure credible." $" 33$

On March 17, Secretary of Defense Melvin Laird outlined the dangers of nuclear development to U.S. interests in the Middle East. ${ }^{34}$ Critical phrases remain blacked out in the declassified document, but as Israel was the only state in the region believed to be developing nuclear weapons, along with the missiles capable of carrying them, it is not difficult to connect the dots and identify who and what the secretary was talking about. In June and October 1968, export licenses had been granted for the supply of two CDC 6400 computers and one IBM 360/65 computer, regarded as critical tools in a (blacked out) country's nuclear or nuclearweapons research and development. One CDC 6400 computer had already been shipped, and the secretary recommended that the other be withheld until "we have had the opportunity to discuss this whole problem area." 35

For Joseph J. Sisco, half measures, "such as attempting to use Israeli requests for conventional weapons as leverage on this issue," would be futile. ${ }^{36}$ The administration's capacity to head off nuclear development, he wrote, "basically hangs on the extent to which we are willing to make this a crunch issue with Israel." Echoing the advice already given by Henry Owen, the United States would have to show that "we are prepared to have the issue become public and to defend our position in the face of domestic pressure."

On April 11, in National Security Study Memorandum (NSSM) 40, Nixon took up the specific question of Israeli nu- 
clear-weapons development, requesting a review of all possible options. The request was followed through by the formation of a committee consisting of Dr. Kissinger (the chairman) and representatives of the CIA, the Joint Chiefs of Staff and senior figures from the Departments of State and Defense. By now, it was widely assumed within the administration that Israel had already succeeded in developing a nuclear weapon, changing the focal point of

Kissinger stressed the need to disinguish between Israel's secret possession of nuclear weapons and public knowledge of their existence, which he regarded as "almost as dangerous as possession itself ...." a demolition of the systems or merely hidden storage and whether we should insist on inspection rights." 39

The consensus view eventually reached was that Israel should be asked for a commitment that it would not develop a nuclear weapon, forcing it to hide discussion from prevention to accommodation and the safeguards the United States still wanted Israel to accept.

On June 26, the issues were reviewed at a meeting headed by Kissinger's committee. ${ }^{37}$ It was noted that, while there was substantial agreement between government agencies on what the United States wanted from Israel, "there were significant differences as to the degree of pressure we were ready to apply [and] whether the threat of pressures should be implicit or explicit." 38 Rather than seeking a commitment from Israel not to produce nuclear weapons, Kissinger believed the United States should now seek "private, bilateral assurances that Israel would not deploy or test nuclear explosive devices." Furthermore, "we should seek to create circumstances in which Israel would not 'announce' a nuclear capability and would maintain secrecy on its research and development activity." In Kissinger's opinion, the United States should avoid a direct confrontation with Israel, "as well as public knowledge of Israeli nuclear activities. We should also determine whether we are going to ask for its program and limiting any aspect of collusion. This implied an acceptance of Israel's definition of "develop," which was that a nuclear bomb could not be said to have been "introduced" or "developed" until tested and fully assembled. In other words, as long as all the parts of a nuclear weapon were not fully assembled, it could not be said to have been developed. What was being advocated was a policy of tacit acceptance of what the United States suspected and almost certainly knew. Israel could not be stripped of weapons it had already produced, but as long as it agreed not to develop weapons and agreed to keep research and development under wraps, the United States would be able to feign ignorance of the reality.

The same argument was used with regard to missiles acquisition and deployment. By this time, it was believed that Israel already had 11 or 12 nuclear-capable surface-to-surface M-620 Jericho missiles (developed and tested in France) and would have 25 to 30 by the end of 1970 , 10 of them programmed for nuclear warheads. Once these missiles were deployed, "the whole world would be convinced that Israel had nuclear warheads." ${ }^{40}$ Accordingly, Israel's agreement "not to deploy missiles it produced but to keep them hid- 
den might be easier to maintain and [would not] be completely inconsistent with U.S. interests." Although the United States was now watering down its objectives, using the supply of F-4 Phantom fighter aircraft as a bargaining counter did not seem likely in view of Nixon's attitude: "K [Kissinger] said he had talked with Pres[ident] this morning and he is very leery of cutting off phantoms [sic]." 41

Early in July, the "issues for decision" were reviewed. ${ }^{42}$ The recommendations to be sent to the president included continued pressure on Israel to sign the NPT before the end of the year alongside "our unstated objective to keep Israel's nuclear weapons from becoming public knowledge" and "our stated purpose for internal working purposes to stop Israel from assembling completed nuclear devices." Israel would also be asked to reaffirm that it would not be the first country to introduce nuclear weapons into the Middle East, with introduction specified to mean the "possession of nuclear explosive devices." On the tactics to be adopted in getting assurances from Israel, "the issue is whether we are prepared to imply - and to carry out if necessary - the threat not to deliver the Phantoms if Israel does not comply with our request" [emphasis in original].

With Nixon having already made it plain that he would support this kind of pressure, a "gentle approach" minimizing "the atmosphere of confrontation" was ultimately adopted. On the question of nuclear-capable missiles, it was suggested that Israel be asked not to deploy the missiles and halt their production, "but that we be prepared to settle for their agreement not to deploy." As with nuclear weapons, "the significant act is general public awareness of the weapon, and this would surely follow from deployment of these missiles to launching pads. What non-deployment means is that Israel could produce the missiles and then put them in a shed instead of in the launching area. ${ }^{943}$ Kissinger stressed the need to disinguish between Israel's secret possession of nuclear weapons and public knowledge of their existence, which he regarded as "almost as dangerous as possession itself .... What this means is that while we might ideally like to halt actual Israeli possession, what we really want at a minimum may be just to keep Israeli possession from becoming an established international fact." ${ }^{4}$

On July 28, Sisco set out talking points for upcoming discussions with Yitzhak Rabin, who was still the Israeli ambassador. ${ }^{45}$ Israeli and U.S. negotiators met the following day. Present on the U.S. side were Acting Secretary of State Elliot Richardson, Under Secretary of Defense David Packard and Alfred L. Atherton, the country director on Arab-Israeli affairs. ${ }^{46}$ Representing the Israelis were Rabin, embassy minister Shlomo Argov (the target in 1982 of an assassination attempt in London that was used by Israeli Prime Minister Menachem Begin as a pretext to attack Lebanon), and embassy counsellor Moshe Raviv. Richardson began by reading a statement of concern over the prospective introduction of nuclear weapons and delivery systems into the Middle East, warning that the United States would regard this "as a direct threat to United States national security." Washington attached great weight to assurances given by Israel, but with the NPT now in existence, he added, "unilateral assurances are no longer sufficient in themselves to give the world confidence that Israel does not intend to manufacture nuclear weapons."

Israel was not just another state that was stalling on the question of adhering to 
the NPT. It had the technical capacity to build nuclear weapons, and the world was also becoming aware that it was acquiring missiles capable of carrying nuclear warheads. Because it was so close to the nuclear-weapons threshold, Richardson asserted,"Israel's attitude toward the NPT is being closely watched by other small and medium-sized states who are waiting to see whether nuclear-weapons non-proliferation can be made to prevail as a global principle. We therefore attach utmost importance to Israel's early signature and ratification of the NPT." Richardson also made it clear that the United States regarded the actual possession of nuclear weapons as equivalent to introducing them, irrespective of whether they were untested and unadvertised. On all of these questions, Rabin stalled, and talks ended without his giving any of the assurances being sought.

The United States was still trying to find out what was happening at Dimona through the visits of scientists. A team visited in early July, but it had not been able to make a full examination. ${ }^{47}$ Reviewing the history of these visits, Robert $\mathrm{H}$. Munn of Near Eastern Affairs reported that Atomic Energy Commission (AEC) officials had drawn the inference that the U.S. government was not prepared to support real inspections. In many subtle ways the team had been cautioned to avoid controversy and not take issue with the obvious will of the hosts. ${ }^{48}$ In the absence of a "positive mandate" to inspect, "with all that word implied," the AEC team

did not make an issue of the fact that the program drawn up by Israel shifted timing and focus in important ways, which limited their access to key facilities. Nor did they take issue with their host's obvious pushing and hurrying past points at which they indicated a desire for a closer look. The fact that the team avoided creating issues can give rise to the semantic interpretation that what went on satisfied them, which is in essence what the Israelis replied to the Embassy.

The AEC team went on to caution that the visits could even be regarded as counterproductive because they could be used in the future as evidence of "cooperation" and "U.S. satisfaction" 49

On September 8, Richard Helms sent a message to Richard Nixon in an envelope marked "For and to be opened only by: The President." disclosed, and indeed are not to be found in the archives, but almost certainly the subject was Israeli nuclear-weapons development. ${ }^{51}$ Mrs. Meir was due to arrive later in the month. In the weeks beforehand, the U.S. position was reaffirmed in two important documents, one a Memorandum for the President by Secretary of State William P. Rogers on the "suggested position" to take with the Israeli prime minister, ${ }^{52}$ and the second a background paper written for Dr. Kissinger. Rogers regarded the Meir visit as offering an opportunity

to get across clearly to her why we believe Israel's stand-pat policy is detrimental to both U.S. and Israeli interests and no longer tenable in the situation we now face, both in the area and the diplomatic field. In doing so we should, I believe, seek to prepare the Israelis for moves on our part designed to counter the growing impression in the world that we support territorial expansion as a legitimate Israeli peace aim.

At the same time, Rogers advised, Israel should be reassured on the U.S. com- 
mitment to its security, although there was no need to give Mrs. Meir a firm answer before the end of the year. ${ }^{53}$

In the background paper written for Dr. Kissinger, ${ }^{54}$ it was noted that, while Israel "resents our position," it may have concluded that "since we have not gone beyond words in pressing our point, we are actually resigned to seeing Israel become a nuclear power." Israel seemed to have applied the axiom, "Never mind what they say, it's what they do that counts." ${ }^{55}$ In this respect, the United States had increased the level of arms sales to Israel "virtually without condition." In conclusion, "It seems clear that only substantial pressure in an area sensitive to Israel could change Israel's determination to avoid meaningful discussion of the nuclear problem."

On September 26, Nixon met Meir in the Oval Office. What they discussed in private remains mostly out of sight. ${ }^{56}$ Kissinger was briefed but "apparently remained only partially informed" about the nature of the talks. ${ }^{57}$ There is an indication of the substance, however, in his observation to the president that "during your private discussions with Golda Meir you emphasized that our primary concern was that Israel make no visible introduction of nuclear weapons or undertake a nuclear test program." 58 This account suggests, moreover, that possibly Mrs. Meir acknowledged, "tacitly or explicitly," that ${ }^{59}$ Israel had the bombs "and may have assured Nixon that Israel thought of nuclear weapons as a last-resort option." ${ }^{\prime 60}$

The central issue was not the development of nuclear weapons or their possession. Most probably Nixon and Meir agreed that, if Israel did not draw attention to its nuclear activities, the United States would look the other way. In Kissinger's view, "What we have to settle for, I be- lieve, is an Israeli commitment that will prevent nuclear weapons from becoming a known factor and further complicating the Arab-Israeli situation." 61 On November 6 , he recommended "that we not press the Israelis any further on this subject at this time." ${ }^{62}$ By this time, elections had been held in Israel and Mrs. Meir had formed a national unity government. On February 23, 1970, Rabin asked Kissinger to pass on the message to Nixon "that Israel has no intention to sign the NPT. The reply to the State Department had been along strictly formal lines, but the Prime Minister wanted to make sure there was no misapprehension about Israel's current intention." Furthermore, Israel would regard any attempt to link arms sales to the NPT as "extremely unfortunate." 63

The official position of the U.S. administration from now on would be, "While in our judgment Israel has the technical and scientific capability to produce nuclear weapons, we have no concrete evidence that it has done so." ${ }^{64}$ At the highest level of government, a tacit understanding had been reached. Israel would insist that it would not be the first country to introduce nuclear weapons into the Middle East, but as long as it did not test weapons, the United States could pretend that it did not really know whether it had them or not. Israel's policy of "opacity" on the question of nuclear weapons was now the policy of the United States as well.

Israel had held its ground during years of negotiations and got everything it wanted without giving anything of substance in return. The role of the White House in preventing the kind of pressure being put on Israel that might have curtailed its nuclearweapon and missile-development programs was central. In no part of the world did the United States seem more determined to 
prevent the acquisition of nuclear weapons than the Middle East. Its positions were expressed forcefully year after year, yet it ultimately backed down from every position it had held. It was unable to prevent Israel from developing nuclear weapons or deploying the missiles that could carry them to any part of the Arab world. It failed to persuade Israel to sign on to the NPT. Its provision of supercomputers enabled Israel to simulate nuclear tests, while the mysterious flash off the coast of South Africa on September 22, 1979, is widely thought to have been the physical test of a nuclear weapon jointly arranged by Israel and the South African government. ${ }^{65}$
The beginning of the nuclear age in the Middle East was to have consequences that are being felt to the present day. No one outside the highest echelons of the Israeli government knows how many nuclear weapons Israel has produced and stockpiled. Outside estimates range from between $60-80$ to about 400 , with the Federation of American Scientists believing the true figure to be probably less than $100 .{ }^{66}$ No one really knows. Iran, which has signed on to the NPT and allows IAEA inspections of (not "visits" to) its nuclear sites, has not produced one, yet is being threatened with military attack.

\footnotetext{
${ }^{1}$ The treaty was opened for signature on July 1, 1968, and came into force in 1970. Israel became a member of the IAEA in 1957 but has not signed the NPT. Iran signed the treaty in July 1968 and ratified it in February 1970.

${ }^{2}$ See William Burr, "A Brief History of U.S.-Iranian Nuclear Negotiations," Bulletin of the Atomic Scientists, January/February, 2009 (online at www.thebulletin.org).

${ }^{3}$ National Security Archive, George Washington University, The Nuclear Vault, "U.S.-Iran Nuclear Negotiations in the 1970s." Document 9b, Tehran Embassy cable 11089 to State Department, November 13, 1975, confidential. Reporting on an interview with the shah in Business Week, later prominently displayed in the Tehran newspaper Kayhan International. http://www.gwu.edu/ nsarchiv/nukevault/ehb268/index.htm. ${ }^{4}$ Dr. Mohamed ElBaradei, introductory statement, IAEA Board of Governors meeting, Vienna, June 2, 2008. http://www.iaea.org/NewsCenter/statements/2008/ebsp2008n005.html.

${ }^{5}$ http://www.dni.gov/press_releases/20071203_releas... "Iran: Nuclear Intentions and Capabilities," National Intelligence Council, November 2007.

${ }^{6}$ On May 17, 2010, Iran, Brazil and Turkey reached an agreement under which Iran agreed to deposit, 1200 $\mathrm{kg}$ of low-enriched uranium (LEU) in Turkey. On April 20, President Obama had written to President Lula of Brazil stating that Iran's transfer of $1200 \mathrm{~kg}$ out of the country "would build confidence and reduce regional tensions by substantially reducing Iran's LEU stockpile." See Flynt Leverett and Hillary Mann Leverett, "President Obama Should Be Honest about the Iran-Turkey-Brazil Nuclear Deal," MRZine, May 27, 2010, http://MRzine.monthlyreview.org/2010/leverett270510.html. On June 10, however, Secretary of State Hillary Clinton announced that the United States would be seeking a new round of sanctions against Iran at the UN Security Council.

${ }^{7}$ Foreign Relations of the United States (FRUS), 1964-68, Vol. XVIII Arab-Israeli Dispute 1964-1967

(Washington, DC: Government Printing Office, 2000). President Johnson, memo to Harriman and Komer, February 21, 1965, pp. 343-46.

${ }^{8}$ Ibid. In the coming years, Israel built nuclear weapons, attacked Jordan and shelled the Banyas waterdiversion project in southern Syria (May 13, 1965) before destroying it altogether on July 14, 1966.

${ }^{9}$ Ibid.

${ }^{10}$ Ibid., p. 231, Lucius Battle, dispatch from Cairo, October 27, 1964.

${ }^{11}$ Ibid., Action Memo from Deputy Assistant Secretary of State for Near East and South Asian Affairs (Handley) to Dean Rusk, Washington, September 8, 1965, pp. 492-93.
} 
Middle East Policy, Vol. XVII, No. 3, Fall 2010

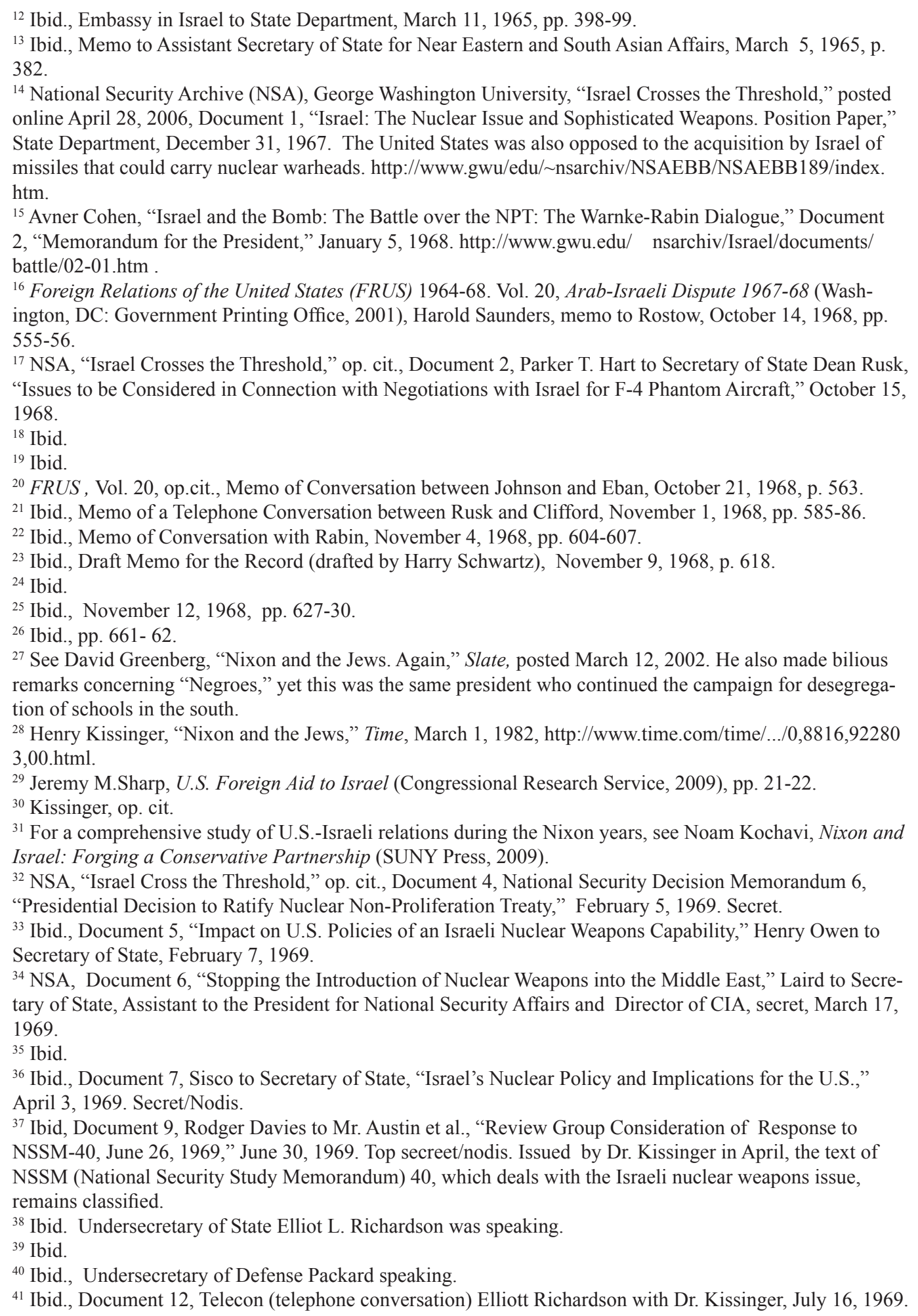


${ }^{42}$ Ibid., Document 10, “The Issues for Decision,” n.d (early July 1969). Top secret/nodis/sensitive.

${ }^{43}$ Ibid., Document 10, “The Issues for Decision,” n.d (early July 1969), Top secret/nodis/sensitive

${ }^{44}$ Henry A. Kissinger, Memorandum for the President, "Israeli Nuclear Program," July 19, 1969. Nodis/sensitive.

${ }^{45}$ Ibid., Document 13, Joseph J. Sisco to the Acting Secretary, "Talking Points for Initial Meeting with Israelis on Nuclear and SSM Issue July 29," July 28, 1969, Top Secret/Nodis.

${ }^{46}$ Ibid., Document 15, Richardson to President, "Israel's Nuclear Program" with memorandum of conversation attached, August 1, 1969, Top Secret/Nodis.

${ }^{47}$ Ibid., Document 16a, U.S. Embassy, Israel, cable 2941 to State Department, "Dimona Visit,” July 31, 1969. Secret/Nodis.

${ }^{48}$ Ibid., Document 16b, Memorandum of Conversation, “1969 Dimona Visit,” August 13, 1969, Secret/Nodis.

${ }^{49}$ Ibid.

${ }^{50}$ Ibid., Document 19, Envelope for President Nixon with Writing by Richard Helms, September 8, 1969.

${ }^{51}$ Avner Cohen and William Burr, "The Untold Story of Israel's Bomb," The Washington Post, April 30, 2006.

${ }^{52}$ NSA, Document 20, Rogers to Nixon, "Suggested Position for You to Take with Israeli Prime Minister Meir during Her Forthcoming Visit," September 18, 1969, with excerpt from separate briefing paper attached. ${ }^{53}$ Ibid.

${ }^{54}$ Ibid., Document 21, Theodore L. Eliot, State Department Executive Secretary, to Henry Kissinger, "Briefing Book - Visit of Mrs. Golda Meir, September 19, 1969," enclosing background paper on Israel's nuclearweapon and missile programs. Top secret/nodis.

${ }^{55}$ Underlining in original.

${ }^{56}$ See Avner Cohen and William Burr, "Israel Crosses the Threshold," Bulletin of the Atomic Scientists, May/ June, 2006, pp. 27-28. According to Walworth Barbour, who was in Washington during the Meir visit, "The President told Under Secretary Richardson and myself on the White House lawn that contrary to his usual practice, he had himself dictated a memorandum of his first conversation with Mrs. Meir at which they were the only participants, and that he had asked Dr. Kissinger, who attended the second meeting, to prepare a similar memorandum covering that session. The President added that, "While he did not want these two papers to be circulated in any regular channels nor in fact even their existence to be known except by a limited few, he specifically wanted Under Secretary Richardson, myself and yourself [Joseph Sisco] to have copies." In the event, he had not seen either, and neither, apparently, had Sisco. National Security Archive, "Israel Crosses the Threshold," Document 26, Harold H. Saunders to Kissinger, December 8, 1969, "Record of the President's Talk with Golda Meir" enclosing note from Barbour to Sisco.

${ }^{57}$ NSA, "Israel Crosses the Threshold," Document 26, Saunders to Kissinger, December 8, 1969, with Barbour letter to Sisco, November 19, 1969. Secret/nodis.

${ }^{58}$ Ibid., Document 22, Kissinger to the President, "Discussions with the Israelis on Nuclear Matters," October 7, 1969. Top secret/sensitive/nodis.

59 “The Untold Story of Israel's Bomb," op. cit.

${ }^{60}$ Ibid.

${ }^{62}$ Ibid., Document 25, Kissinger to Nixon, “Israel's Nuclear Program,” November 6, 1969. Top secret./nodis.

${ }^{62}$ Ibid., Document 28, Memorandum of Conversation, Kissinger and Rabin, February 23, 1970. Top secret/ sensitive.

${ }^{63}$ Ibid., Document 30, Memorandum from [Alfred L.] Atherton and [Myron B.] Kratzer to Mr. Sisco, "Response to Congressional Questions on Israel's Nuclear Capabilities," October 15, 1975.

${ }^{64}$ An American academic, Sasha Polakow-Suransky, has brought to light details of nuclear cooperation between Israel and apartheid South Africa. See "Revealed: How Israel Offered to Sell South Africa Nuclear Weapons," Guardian, May 24, 2010. Under an agreement signed by Shimon Peres, then Israel's defense minister, and South African Defense Minister P.W.Botha, the documents appear to show that Israel offered to provide South Africa with nuclear warheads in three different sizes. Peres has denied the validity of the claim. ${ }^{65}$ Federation of American Scientists (FAS), "Nuclear Weapons," http://www.fas.org/nuke/guide/israel/nuke/. 